\title{
NOVAS TECNOLOGIAS E DIREITOS HUMANOS: UMA REFLEXÃO À LUZ DA CONCEPÇÃO DE ESFERA PÚBLICA
}

\author{
NEW TECHNOLOGIES AND HUMAN RIGHTS: AN INSIGHT UNDER THE LIGHT THE PUBLIC \\ SPHERE CONCEPTION
}

Têmis Limberger*

Maria Eugenia Bunchaft"*

Resumo: No artigo destaca-se a compatibilização das novas tecnologias e da proteção dos direitos humanos na atualidade, diante das manifestações nas redes sociais que pretendam a ampliação do espaço democrático na esfera pública. Nesse contexto, com a expansão do espaço virtual, o conceito de cidadania - então atrelado à ideia de território físico - deve ser repensado a partir da proposição de Pérez Luño - ciberciudadanía o ciudadanía.com. Neste artigo sustenta-se que a concepção habermasiana estabelecida em Faktizität und Geltung, baseada em um modelo de eclusas que atribui à esfera pública papel mais ofensivo, e os aportes teóricos delineados em Sobre a Constituição da Europa, atendem aos desafios propostos pela necessidade de conceber o espaço de informação na internet como uma arena efetiva de exercício dos direitos humanos. Aduz-se que a perspectiva de Fraser, assumindo o Princípio de todos os Sujeitados, revela maior alcance teórico para a compreensão da luta política por justiça global, especialmente em se tratando da ideia de contrapublicidade, que pode ser incrementada pela mobilização virtual. Contudo, é importante que o mundo virtual tenha sua normatização e não se transforme em um far west informático. Utilizou-se o método fenomenológico-hermenêutico e uma técnica de pesquisa baseada na documentação indireta.

Palavras-chave: Informação pública. Novas tecnologias. Democracia. Direitos humanos. Esfera pública.
Abstract: In this paper, the compatibility of the new technologies and protection of human rights at present is highlighted, given the actions on social networks that wish the expansion of the democratic space in the public sphere. In this context, with the expansion of virtual space, the concept of citizenship - that was linked to idea of physical territory - should be rethought from de Pérez Luño proposition - cyber citizenship or citizenship.com. In this article it is sustained that Habermas's conception, established in Faktizität und Geltung, based on locks model that gives the public sphere a more prominent role, as well as theoretical contributions outlined in Sobre a Constituição da Europa, attend to the challenges posed by the need to design the information space on the internet as an effective arena of exercise of human rights. It is argued that Fraser's perspective, assuming the All-Subjected Principle, reveals more theoretical power to understanding the political struggle for global justice, especially with regard to the idea of counterpublicity, which can be increased by virtual mobilization. However, it is important that the virtual world has its regulation and does not become a far west. It was used the hermeneutic phenomenological method, and a research technique based on indirect documentation.

Keywords: Public information. New technologies. Democracy. Human rights. Public sphere.

\footnotetext{
"Pós-doutora em Direito pela Universidade de Sevilha; Doutora em Direito Público pela Universidade Pompeu Fabra de Barcelona; Professora do Programa de Pós-graduação em direito da Universidade do Vale dos Sinos; Avenida Unisinos, 950, Cristo Rei, 93022-000, São Leopoldo, Rio Grande do Sul, Brasil; temis@via-rs.com.br

" Pós-Doutora em Filosofia pela Universidade Federal de Santa Catarina; Doutora e Mestre em Teoria do Estado e Direito Constitucional pela PUC-Rio; Professora do Programa de Pós-Graduação em Direito da Universidade do Vale dos Sinos; mbunchaft@unisinos.br
} 


\section{Introdução}

Uma das questões fundamentais que permeiam a atualidade se concentra em buscar respostas para a seguinte indagação: como compatibilizar as novas tecnologias e a proteção dos direitos humanos, em suas manifestações nas redes sociais que pretendam a ampliação do espaço democrático? Nessa perspectiva, para Habermas (2003, p. 304), “[...] somente uma cidadania democrática, que não se fecha num sentido particularista, pode preparar o caminho para um status de cidadão do mundo, que já começa a assumir contornos em comunicações políticas em nível mundial."

Por conseguinte, a cidadania estatal e a mundial aproximam-se visivelmente, no dizer de Habermas (2003, p. 304), haja vista que o conceito de cidadania (que era vinculado ao Estado-Nação) se modificou com o mundo globalizado e precisa ser revisto, no intuito de universalizar os direitos humanos. De mais a mais, os acontecimentos transcendem as fronteiras dos países e os fenômenos não ocorrem mais isoladamente - mas globalmente - e as crises políticas e econômicas não atingem somente um país, mas repercutem mundialmente.

Nesse contexto, os meios eletrônicos - que transmitem a informação em uma velocidade nunca antes conhecida pela história da humanidade - podem cumprir papel importante, qual seja, a democratização. A internet pode ser utilizada para compras e para operações bancárias (configurando relações de consumidores) ou para denunciar importantes violações de direitos humanos, como ocorreu nos países árabes - Egito, Tunísia, Iêmen, Jordânia e Argélia (SORG; MACHADO, 2011).

Nessa perspectiva, o movimento conhecido como Indignados (HESSEL, 2011), que se iniciou na Espanha e se propagou por diversos países, inclusive no Brasil (CASTELLS, 2013) - sem que por detrás estivesse algum partido político, movimento sindical ou associativo - também merece reflexão. Foi por meio da internet que a população - em grande parte, a juventude - se organizou pacificamente e, assim, protestou contra o modelo político europeu existente (que, por vezes, é indiferente, não respeitando a pauta dos direitos humanos). Por tais razões, as políticas governamentais têm acarretado altas taxas de desemprego, principalmente entre os mais jovens.

Portanto, é premente apontar que o principal problema enfrentado neste trabalho é, partindo da perspectiva de Fraser $(1997,2009,2010)$, questionar em que medida o espaço virtual pode incrementar a democracia no caminho da efetividade dos direitos humanos, mediante a lógica da contrapublicidade delineada por sua teoria?

O presente estudo contempla como objetivo geral analisar em que medida, diante de um contexto de transformação estrutural da ordem mundial, uma rede de comunicação entre movimentos da sociedade civil global, a partir de contrapúblicos subalternos, pode potencializar a deliberação democrática, garantindo efetividade nas lutas para a efetivação dos direitos humanos. Para tal empreendimento, defende-se que a democracia deve pressupor o pluralismo informativo e o livre acesso à informação.

Nesse ponto, à luz das perspectivas de Chevallier (2009) e Cassese (2010), assume-se, como primeiro objetivo específico, a proposta de refletir criticamente sobre a crise do conceito de cidadania vinculada ao Estado-nação. Para tanto, contrapõem-se as perspectivas dos autores supracitados 
às concepções tradicionais sustentadas, por exemplo, por Zanobini (1955). Ao ensejo, propugna-se atribuir ênfase ao referencial teórico de Arendt, que trata do "direito a ter direitos", assim como o de Delmas-Marty (2010), que, por sua vez, refere-se a uma solidariedade transnacional desvinculada da concepção tradicional de cidadania.

Incorpora-se como segundo objetivo específico analisar a ideia de Direito Artificial, de Frosini (1982), que ressalta que, pela primeira vez na história da humanidade, os conflitos sociais e jurídicos seriam travados por máquinas e por homens, em razão da intermediação dos computadores, o que subverteria a tradição - até então existente - de os conflitos serem gerados apenas nas relações oriundas dos homens. Por fim, analisa-se a concepção de um dos seus discípulos - Pérez Luño (2004) - que examinou a perspectiva da ciberciudadanía, a fim de indicar a perspectiva da informática e a cidadania em um mundo globalizado.

Tem-se como terceiro objetivo específico: a estratégia de relacionar a evolução conceitual da ideia de esfera pública na obra de Habermas (1962, 1992b, 2012) estabelecida desde Strukturwandel der Öfentlichkeit até Faktizität und Geltung, assim como as inovações teóricas delineadas em Sobre a Constituição da Europa, no que se refere à transnacionalização da soberania popular, com a possibilidade de conceber o espaço virtual como uma arena de exercício dos direitos humanos.

De outro lado, objetiva-se, em quarto lugar, investigar em que medida a perspectiva de Fraser (2010) - ao pressupor "o princípio de todos os sujeitados" - revela maior alcance teórico para a compreensão da luta política por justiça global, especialmente no que se refere à lógica da contrapublicidade, que pode ser incrementada pela mobilização virtual. Por fim, resgata-se a perspectiva de Kurusawa (2014), que se apropria da ideia de contrapublicidade - delineada por Fraser - conectando-a a um cosmopolitismo anarquista viabilizado por movimentos radicais da sociedade civil global.

Para tanto, o trabalho se desenvolve pelo método fenomenológico-hermenêutico, que pretende a aproximação entre sujeito e objeto a ser pesquisado. Segundo Stein (1979), não se trata de uma análise externa, como se sujeito e objeto estivessem desconectados. Diferentemente, o sujeito está implicado diretamente, relacionando-se com seu objeto de estudo, interagindo com este e sofrendo os efeitos de seus resultados de pesquisa. Logo, o pesquisador está inserido no mundo em que a pesquisa foi realizada. No movimento do círculo hermenêutico, a pré-compreensão do pesquisador é anterior à sua compreensão e à sua interpretação, o que atribuiu significado aos resultados da pesquisa.

Incorporando como técnica de pesquisa a documentação indireta, assume-se a primeira hipótese segundo a qual a transformação estrutural da ordem mundial e a concretização de uma justiça global voltada para os direitos humanos somente podem ser efetivadas por uma opinião pública que reflita um distanciamento engajado em relação às instituições formais da governança global, considerando a lógica da contrapublicidade preconizada por Fraser $(1992,1997)$.

Tem-se como segunda hipótese a defesa da importância do espaço virtual em potencializar o ideal democrático mediante a lógica da contrapublicidade - ou seja, dando efetividade aos direitos humanos e às demandas da sociedade civil global. No entanto, sustenta-se como terceira hipótese a 
necessidade de regulamentação de determinados aspectos jurídicos, evitando o surgimento de um far west informático.

A internet configura uma grande conquista para a humanidade, e a informação é transmitida a uma velocidade sem precedentes históricos. Porém, como todo fenômeno complexo, não é algo que contenha apenas aspectos positivos ou negativos, e sim, uma ferramenta que pode ser utilizada de forma ambígua, pois comporta elementos que, por ora, agregam e, por vezes, desagregam. Ademais, representa uma experiência tecnológica, mas o uso que dela é feito se opera pela mão humana e, por isso, não é bom, nem ruim, unicamente dependendo da sua utilização.

Nesse panorama, cabe mencionar a analogia proposta por Sunstein (2003, p. 105), ao referir a Convenção de Filadélfia. Quando Franklin saiu do edifício, alguém do povo perguntou: que nos vão a dar? À pergunta, respondeu: uma república, se souberem conservá-la. Desse modo, o comentário de Franklin deveria se constituir em constante recordação de uma obrigação que é posta. Na hora de manter uma república, o texto fundacional tem muito menos importância com o passar do tempo do que as ações e os compromissos da cidadania nacional.

Por isso, não prospera a ideia da "[...] confiança utópica em um ciberespaço ideal" (PÉREZ LUÑO, 2006, p. 102), como se no plano das relações virtuais fosse possível deixá-los imunes às vicissitudes humanas. Além do mais, em pleno século XXI, a pauta dos direitos humanos, com seu conteúdo universal, ainda não tem plena aplicabilidade em muitos locais do mundo.

A ideia de que seria possível criar um mundo perfeito na rede, que fosse isento de problemas, que transcendesse as injustiças e que, por conseguinte, fosse desnecessária a regulação jurídica, não prosperou, pois a internet não é espaço neutro - veja-se a questão dos hackers, dos spams, da pedofilia, da violação de dados pessoais e da exclusão digital. Tudo isso faz concluir que as agruras da vida real encontram no terreno virtual espaço fértil para a sua disseminação, e o desafio consiste em utilizar o espaço de informação na internet em prol da efetividade dos direitos humanos. Feitas essas considerações, passa-se a examinar a perspectiva de Frosini.

\section{Frosini e o homem artificial - L'uomo artificiale}

A preocupação com a chegada das novas tecnologias e suas repercussões na seara jurídica ocorre a partir dos filósofos do direito, em uma síntese apertada, especialmente com Denninger (1987, p. 271), na Alemanha, com Frosini (1986), na Itália, e com Pèrez Luño (2010, 1996), na Espanha. Uma das grandes contribuições de Frosini foi a de conceber a expressão "O homem artificial". O contexto em que a expressão foi cunhada é o período pós-Segunda Guerra Mundial. Transcorrida a etapa inicial da Declaração dos Direitos do Homem e do Cidadão, com seu conteúdo universal, e do surgimento do constitucionalismo, no final do século XVIII, assiste-se à chegada do pensamento racional e, posteriormente, do positivismo jurídico. Entre as consequências, tem-se o rompimento entre fato e valor, entre lógica e ética, do qual se evidencia a busca da certeza do direito.

Com o advento de duas guerras mundiais, na primeira metade do século XX, toda a crença no direito como propulsor da paz social entre os povos sufraga. Como consequência, a partir da se- 
gunda metade daquele século, surge o renascimento do Direito Natural, ou seja, a revalorização dos princípios éticos que servem para justificar os mandatos legais e sua eficácia. Por isso, a expressão que abarca os direitos invioláveis do homem é fruto das Constituições pós-Segunda Guerra.

Então, em virtude da presença das novas tecnologias, chegou-se à era do "Direito Artificial" - expressão que se emprega com o propósito de contrapô-la ao "Direito Natural" - considerando que a antítese da natureza, a physis dos gregos, é a expressão grega tecné, isto é, criação artificial (FROSINI, 1982, p. 24). Assim, a artificialidade (reconhecida como característica do direito na época da automação) se caracteriza como uma metáfora empregada para precisar o momento lógico-formal constitutivo da experiência jurídica, em consonância com o momento ético, enquanto entre ambos se mantém e transcorre a tensão da consciência humana, a partir da qual brota toda a norma, toda a sentença, toda a ação jurídica.

O "Direito Artificial" representa um modelo - quase um mito - que exerce particular atração nas sociedades de tipo tecnológico avançado, suscitando, ao contrário, perplexidade e desconfiança, uma vez que os juristas são acostumados à tradição humanista. Não se pode negar as influências que tais perspectivas oferecem ao pensamento jurídico.

Sob esse aspecto, as possibilidades de aplicação da tecnologia significam uma alteração comportamental, constituindo-se como segunda e renovada natureza (FROSINI, 1982, p. 58-59). A expressão direito artificial é correlata ao "homem artificial", isto é, designa um novo tipo de homem, que não foi produzido pela natureza, mas por ele próprio.

Frosini (1981, p. 110) cunha a expressão "liberdade informática" como um novo direito, com o significado de autotutela da própria identidade informática, ou seja, o direito de acessar, de retificar ou de cancelar os dados pessoais inscritos em um banco de dados informatizado. Para outros teóricos, poder-se-ia entender como a outra face do direito à intimidade, ou seja, o direito de não ser molestado, configurando-se como aspecto negativo, enquanto o direito de aceder, de retificar ou de cancelar os dados simbolizaria um aspecto positivo (LIMBERGER, 2007, p. 103). A tese de um novo direito restou vencedora, pois foi consagrado o direito à proteção dos dados pessoais, no $\operatorname{artigo~} 8^{\circ}$ da Carta dos Direitos Fundamentais da União Europeia (2000).

Deve-se também a Frosini a percepção de que a informática significa uma nova forma de poder político e social. Assim, o mundo contemporâneo se caracteriza pela produção, pela circulação e pelo consumo de informação, o que, por suas dimensões, não encontra precedentes na história da humanidade (FROSINI, 1984, p. 30).

Outrossim, a comunicação passou por quatro fases, ao longo da história: a primeira é marcada pela comunicação oral dos povos primitivos; a segunda surge com o alfabeto, que permite a transmissão do conhecimento para outras gerações; a terceira é consagrada pela imprensa, que possibilita que a informação seja difundida rapidamente para um grande número de pessoas; já a quarta ocorre com os meios de comunicação em massa, como o rádio, o cinema, a televisão e os computadores (FROSINI, 1982, p. 173).

Diferentemente do que acontece com a eletricidade, com os computadores interligados em rede há transmissão da informação e, consequentemente, de poder (NORA, 1982, p. 18). Desse 
modo, a possibilidade de transmitir e de armazenar conhecimento não possui precedentes na história da humanidade.

Destarte, a teoria dos direitos humanos somente será capaz de responder às demandas atuais se estiver sintonizada com a revolução tecnológica, na qual se encontra a "consciência tecnológica". Por isso, segundo Pérez Luño (2009, p. 454), a contribuição filosófico-jurídica mais importante de Frosini foi estatuir que a consciência jurídica não se esgota na mera consciência "nomológica", isto é, na atividade do jurista tendente ao conhecimento e à elaboração dos materiais normativos imediatos, senão que se amplia na exigência reflexiva e crítica, a partir da consciência geral dos valores e da ciência. Assim, a perspectiva que se instala é no sentido de pensar a atual configuração do Estado, dos Direitos Humanos e da Constituição, nesse tripé proposto por Pérez Luño (2010), no contexto de sociedade da informação, em que os três elementos não são estáticos, mas interagem entre si.

Em razão do seu afastamento da natureza - criando-se então um mundo artificial, aí entendido como tecnológico - o homem sentiu necessidade de reaproximar-se dela e, talvez por isso, a preocupação com a qualidade de vida e com o meio ambiente tenham dominado o cenário mundial. A evolução da doutrina constitucionalista aponta para o compromisso central do constitucionalismo do Estado ecológico, na concepção de Sommermann apud (PÉREZ LUÑO, 2012).

Portanto, como afirma Pérez Luño (2012, p. 62), a grande tarefa do paradigma jurídico ecológico consiste em reformular o adágio latino, nos seguintes termos: "Faça-se justiça ambiental, para que não se destrua o mundo."

\section{A crise do conceito de cidadania e o fim do Estado-Nação}

Estado Moderno surge como organização política sintonizada com o constitucionalismo e evidencia dois escopos: a limitação dos poderes do Estado e a declaração dos direitos fundamentais. A princípio, cria-se como ideal de racionalidade, e o Estado-Nação - que tinha em suas fronteiras físicas um dos seus elementos que o caracterizavam - soçobrou. Desse modo, a noção de território, poder (soberano) e povo (JELLINEK, 2005, p. 495-604), que orientou a configuração do Estado, perde destaque.

A modernidade, que foi uma resposta ao absolutismo monárquico, teve a necessidade de acentuar o caráter individual, que se encontrava sufocado e sem expressão perante o soberano. Porém, a resposta conduziu a um individualismo exagerado, o que é um dos males da modernidade, de acordo com Chevallier (2009, p. 16). Assiste-se à "absolutização do eu", desenvolvendo-se uma cultura de que "[...] estimam nada dever à sociedade, mas tudo exigem dela"; o referido hiperindividualismo leva a uma nova relação com o coletivo.

Assim, o cidadão, quando está diante desse espaço virtual, não considera as relações que pode travar desde o ponto de vista social - mas apenas individual, escondendo-se atrás de uma tela, por vezes. Repete-se, assim, a nota acentuada de individualismo e de consumismo presente na sociedade.

No entanto, na pós-modernidade, Direito, política e Estado estão a sofrer modificações, cada um em seu aspecto particular e todos reciprocamente. A informação que circula livremente, em 
rede, bem como a possibilidade e a facilidade de transferir capital por meio eletrônico, fazem com que os conceitos de fronteira física e de território percam o seu significado e a sua importância. $\bigcirc$ conceito de cidadania foi atrelado ao de nacionalidade, e, com a derrocada do Estado-Nação, começa-se a reformular seu conceito e seu significado.

O tradicional binômio Estado-cidadão se encontra em crise, na lição de Cassese (2010). Durante as primeiras décadas do século XX, prevaleceu a ideia de duas forças que conviviam dentro do Estado: o poder público, com sua autoridade, e os cidadãos, com sua pauta de direitos fundamentais. Para Giannini (1950, p. 71), isso é o que se extrai da seguinte passagem:

Nas comunidades estatais atuais (Estado comunidade) há, por um lado, as autoridades públicas que se exprimem no Estado organização; por outro lado, as pessoas, sujeitos privados, cidadãos [...] que possuem alguns direitos fundamentais. Existem, portanto, duas forças nas comunidades estatais, a autoridade e a liberdade, que possuem centros de apoio e de expressão.

Por essa visão tradicional criada após o medievo - em que não havia diferenciação entre Estado e sociedade civil - revela-se o contraste entre o Estado e o cidadão, como dois polos que se encontram em oposição. $O$ paradigma bipolar é tensionado com a ideia de justiça administrativa, a que o cidadão recorre para se defender das imposições que lhe coloca o Estado. Esse fórum legitima e fortalece essa distinção. Nesse sentido, dentro da visão tradicional (ZANOBINI, 1955, p. 203), o direito público desenvolve a direção positiva de poder e de mando, enquanto o privado sintetiza apenas o limite externo.

Além disso, a leitura do princípio da legalidade (segundo o qual a administração pode fazer apenas o que a lei autoriza, e o cidadão pode fazer o que a lei não proíbe) evidencia a diferença de procedimentos que se criou a partir da dicotomia liberal entre público e privado, sem os temperamentos que advieram da publicização do direito privado ou da privatização do direito público.

Assim, referidos conceitos não podem mais ser estudados como oposição, mas têm a possibilidade de se interpenetrarem. Essa nova forma de pensar o saber jurídico sinaliza para uma reflexão na qual não existe, a priori, a prevalência do interesse público sobre o particular com o simples argumento de autoridade. Por outro lado, não limitar o nacional como sendo somente o cidadão conduz a uma nova interpretação dos direitos.

O fundamento dos direitos não é a cidadania (aí atrelado o Estado-Nação), mas a ideia de humanidade, que outorga os direitos - ou "o direito a ter direitos". Arendt (1989, p. 343) situa a decadência do Estado-Nação no período que sucedeu a Primeira Guerra Mundial: a inflação foi avassaladora, o desemprego atingiu grandes proporções, as guerras civis assolaram os países, migrações de grupos ocorreram e, diferentemente do que ocorreu nas guerras de religião, não foram bem recebidos em nenhum local, e quando deixaram seus países, tornaram-se apátridas.

Em suma, segundo Arendt (1989), a fundamentação da ideia de direitos humanos com base na ideia de um homem universal e abstrato minimiza a atividade que atribui dignidade ao ser humano: a ação política. Esta representa a interação do homem concreto com outros homens. $\bigcirc$ homem torna-se desprovido da relevância da fala e do relacionamento com outras pessoas. Esvazia-se 
o sentido de dignidade dos seres humanos. Essa contradição torna-se evidente no caso dos apátridas e das minorias étnicas que sofrem privação total de direitos.

Por conseguinte, com a emergência das minorias na Europa oriental e meridional e com os apátridas empurrados à Europa central e ocidental, introduziu-se um novo elemento de desintegração. A desnacionalização se converteu em arma poderosa totalitária, e a incapacidade constitucional das Nações-Estado europeias para garantir os direitos humanos àqueles que haviam perdido os direitos nacionalmente garantidos permitiu aos vencedores impor suas regras aos vencidos.

A Declaração dos Direitos do Homem, em 1789, significou que, a partir de então, a fonte da Lei deveria se fundamentar no homem - e não nos mandamentos de Deus ou nos costumes históricos. Por isso, "o direito a ter direitos" (ARENDT, 1989, p. 375) representa viver dentro do marco em que cada pessoa é julgada pelas ações e pelas opiniões próprias e do direito a pertencer a algum tipo de comunidade organizada. Milhares de pessoas perderam o dito status por saírem de seu país, o que justifica a necessidade de retomar tais direitos em uma nova situação política global. Assim, a perda de local e de status político significa a expulsão da humanidade.

Antes disso, o que então se denominava direito humano havia sido considerado uma característica geral da condição humana - e que nenhum tirano poderia suprimir. Sua perda simbolizava a supressão da condição humana, como o que já definira Aristóteles: o homem como animal político, que vive em comunidade. Assim, o indivíduo pode perder todos os denominados direitos do homem, contudo, sem perder sua qualidade especial de homem: sua dignidade. Somente a perda da própria comunidade lhe suprime da humanidade.

O homem do século XX emancipou-se da natureza no mesmo grau em que o homem do século XVIII o fez da história (ARENDT, 1989, p. 377). Nesse aspecto - a ideia de emancipação da natureza - aproxima-se Arendt do pensamento de Frosini, com o homem artificial. Logo, o direito a ter direitos de cada indivíduo teria de ser garantido pela mesma humanidade (daí a máxima de Arendt no sentido de que os direitos não são um dado, mas um construído).

Nesse contexto, a igualdade, em contraste com tudo o que está relacionado à própria existência, não é outorgada, mas resulta de toda a organização humana, tanto que é guiada pelo princípio de justiça. Não nascemos iguais, chegamos a ser iguais como membros de um grupo, por força de nossa decisão de conceder-nos mutuamente direitos iguais (ARENDT, 1989, p. 380).

A queda das fronteiras no mundo virtual reclama da reorganização dos elementos típicos do Estado. Delmas-Marty (2010, p. 253) postula, pela trilogia do saber, querer e poder, a refundação dos poderes, em que o processo cívico de refundação impulsiona o contrato social mundial e o processo jurídico em direção à construção de um estado de direito mundial. Importa também não esquecer de outra condição para a renovação do formalismo jurídico, localizada sob o signo do pluralismo ordenado, fundado em uma comunidade de valores, que será sua condição de possibilidade. Assim, Rousseau se localizaria em uma perspectiva local, enquanto o cosmopolitismo conduziria à ideia de contrato social mundial.

A expressão "bens públicos mundiais" ou "valores comuns da humanidade" (DELMAS-MARTY, 2010, p. 207) tem origem na linguagem adotada pelo Programa das Nações Unidas para o 
Desenvolvimento (PNUD) e pelo Banco Mundial, no início do milênio em curso, inicialmente com foco econômico, mas que resultou de profundos trabalhos e de pesquisas que se realizaram ao longo da última década do século XX, visando a transformar o conceito de desenvolvimento em algo mais comprometido com a mesma ideia de qualidade de vida. ${ }^{1}$ Relaciona-se, ainda, à busca de uma resposta à globalização pela via da solidariedade transnacional e transtemporal, cuja melhor gestão depende do fornecimento - e da consideração - desses (bens públicos mundiais).

Delmas-Marty (2010, p. 207) recorda que a ideia de que possa existir a solidariedade transnacional desconectada do peso da soberania não é recente, uma vez que Hugo Grotius a referiu quando tratou de questões ligadas ao alto-mar. Todavia, a herança nociva, pessoal - individual e coletiva - e a herança material deixadas pelas duas grandes guerras do século XX, somadas às derivas ecológicas produzidas no mesmo período, deflagraram novos anseios. A imbricação recíproca entre esses dois universos - resultados das guerras e das violações ecológicas - fez com que surgisse o conceito de "patrimônio comum da humanidade" (DELMAS-MARTY, 2010, p. 207).²

No entanto, a ideia de bens públicos mundiais perpassa a superação da visão que reduz os direitos fundamentais aos direitos do homem (DELMAS-MARTY, 2010, p. 257-280) 3 para tecer uma concepção mais larga, que coloca o universalismo em uma tripla evolução: biológica (hominização), ética (humanização) e tecnológica (globalização) (DELMAS-MARTY, 2010, p. 203).

Ainda para Delmas-Marty (2010, p. 380), se os direitos do homem estão presos entre uma hominização unificadora e uma humanização relativista, são os bens públicos mundiais que poderão reduzir as tensões entre hominização e humanização e contribuir para a emergência de valores universalizáveis para cuja construção o paradigma da tradução deverá exercer papel fundamental na condição de um instrumento político a serviço da ética. Todas essas modificações demonstram que o Estado-Nação soçobrou e cedeu lugar à globalização, em que os direitos humanos pleiteiam o seu reconhecimento, não mais nas fronteiras do Estado, mas em razão da condição humana. Tal desiderato é mais ambicioso e de implementação e efetividade mais complexas.

\section{Ciberciudanía o ciudadanía.com: a proposição de Pérez Luño}

Estudando a origem etimológica do conceito de cidadania até chegar aos dias atuais, Pérez Luño (2004, p. 24) assevera que o termo, historicamente, advém do vocábulo latino cives, o qual designa a posição na civitas. A ideia romana de cidadania referia um núcleo inseparável de direitos e de deveres que definiam a posição das pessoas livres na República.

Coulanges (2001), em sua obra Cidade Antiga, leciona que a cidade se constituiu, desde a própria gênese da evolução histórica da humanidade, como um local de segurança, um espaço de comodidade e um estímulo à cultura. Representou, ainda, uma primeira garantia de segurança.

\footnotetext{
Cujo pressuposto é o desenvolvimento das capacidades humanas.

2 O Embaixador de Malta - Arvid Pardo - lançou, em 1967, o conceito de "patrimônio comum da humanidade". A referência do diplomata ocorreu a propósito da problemática ligada às águas profundas.

3 No sentido de alargar a concepção para "direitos da humanidade", ou seja, para incluir a natureza e os animais.
} 
Os muros denotavam a sensação de proteção, e fora desse espaço, colocavam-se as incertezas e os perigos. A cidade foi também uma das primeiras tentativas de organizar a "vida boa", na expressão aristotélica (ARISTÓTELES, 1998, p. 76-97).

Designou, ainda, a aproximação das pessoas aos recursos até então existentes: casas, caminhos, mercados, aquedutos e fontes, o que possibilitava o a convivência. A cidade, portanto, será o núcleo da civilização, a própria raiz etimológica da noção de civilidade na vida cívica, na reflexão e na deliberação racional sobre o mundo e a sociedade.

A época em que a cidadania adquire novo significado é o Iluminismo, quando se constata uma nova concepção vinculada à noção de liberdade política. $\bigcirc$ conceito moderno de cidadania coincide temporalmente com o de direitos humanos e de Estado de Direito. A Revolução Francesa exaltará a qualidade de cidadãos, no contexto dentro do qual exaltará liberdades, que serão exercidas em um contexto de Estado de Direito (PÉREZ LUÑO, 2004, p. 35). Por fim, os conceitos de cidadania, de direitos fundamentais e de Estado de Direito estarão imbricados em determinado momento político, constituindo-se uma marca da modernidade. A origem do conceito de cidadania também se encontra relacionado à questão de nacionalidade, em que ser cidadão equivalia, no Estado Liberal, a ser nacional de um Estado. Nas sociedades plurais do nosso tempo, os Estados englobam realidades complexas e termos de multiculturalidade e de multinacionalidade, e, desse modo, a relação entre cidadão e nacional restou perdida.

O tradicional binômio Estado-cidadão está em crise, já alertou Cassese (2010, p. 83). Esse paradigma bipolar, formado historicamente entre sujeitos privados que acudiam à jurisdição administrativa para defender seus interesses particulares, e que durante dois séculos vigorou, hoje vê o binômio público versus o privado modificado. Tradicionalmente, contrapunha-se o administrador ao administrado, daí entendida como postura passiva, em termos de cidadania.

Romano, Zanobini e Giannini (apud CASSESE, 2010, p. 83, 86) resumiram e apresentaram, de maneira exemplar, o paradigma fundamental do direito público do século XX: dois polos separados, nem convergentes ou contraentes, mas em contraposição, por causa da superioridade de um sobre o outro. Para compensar essa superioridade, o mais forte - vinculado a regras e a deveres - deve agir de modo planejado e imposto pela lei e pelo direito, enquanto o privado age conforme o próprio interesse, de modo livre, salvo os limites externos impostos pela lei.

A mudança de referencial em que dois polos eram separados e regidos por princípios diferentes não é negativa, mas sinaliza positividade, já que com as novas relações administrativas se introduzem elementos democráticos de participação popular. O cidadão, com o exercício dos direitos fundamentais em rede, não age mais de forma passiva, mas se torna artífice na construção do processo democrático. Logo, uma das questões postas é a projeção das novas tecnologias no âmbito da participação política dos cidadãos (PÉREZ LUÑO, 2004, p. 57). Atualmente, um dos grandes objetivos da democracia é possibilitar uma rede de comunicação direta entre Administração e administrados, que propicie aprofundamento democrático e maior transparência e eficiência da atividade pública. 
Para tal empreendimento, assumem especial relevância a concepção habermasiana de esfera pública - especificamente, o modelo de eclusas estabelecido em Faktizität und Geltung - e a concepção elaborada por Fraser sobre o mundo pós-westfaliano.

\section{Esfera pública em Habermas e Fraser}

Em Strukturwandel der Öfentlichkeit, Habermas (1962) investiga o desenvolvimento histórico da categoria denominada esfera pública desde o seu surgimento no mundo grego, analisando também sua relevância no mundo feudal e nas sociedades burguesas até as sociedades contemporâneas. Ao se aprofundar sobre a sociedade burguesa, o autor descreve como surge a concepção de família que se autocompreende como esfera capaz de elaborar intimamente a ideia de humanidade.

Começa aqui a surgir um ideal de humanidade, a partir das reuniões íntimas da família burguesa. A ideia do público surge inicialmente como ampliação e complemento da esfera da intimidade familiar, porquanto a privacidade dos quartos de dormir depende da natureza pública do salão. As pessoas privadas, reunidas no salão, passam a discutir publicamente obras literárias e se inserem em um processo de construção iluminista de um ideal de humanidade.

A partir disso, despontam cafés, salões, comunidades de comensais que inspiram uma esfera pública literária oriunda da esfera da intimidade da família. Organizam-se reuniões em que as pessoas vão discutir sobre obras de arte e literárias que, aos poucos, assumem funções críticas. Assim, nasce uma esfera pública política que vai racionalizar o poder.

Habermas (1962) revela como surgem sociedades secretas nas quais se forma o público de pessoas privadas que passam a não mais tratar apenas de questões literárias, mas também políticas e econômicas. Os cafés, as casas de chá, os clubes de leitura e os jornais atraem pessoas que se reúnem para debater questões teóricas e econômicas. $O$ processo de politização da cultura e da arte e o surgimento de debates econômicos e culturais evoluíram para o surgimento de uma esfera pública reflexiva contra o Estado.

Habermas (1962) pondera ainda que, com o desenvolvimento do capitalismo no século XIX e no início do século XX, ocorre a decadência dessa esfera pública crítica e reflexiva, que se converte em uma esfera da manipulação, perdendo funções críticas. Com o surgimento dos meios de comunicação de massa, a esfera pública passa a conectar-se aos interesses privados, esvaziando sua função crítica, por meio de um processo de despolitização.

Examinam-se determinados fatores responsáveis pela perda de função crítica da esfera pública. O primeiro fator foi a conexão entre o setor público e o privado, decorrente do surgimento de um Estado intervencionista na esfera privada no final do século XIX, esvaziando a separação entre Estado e sociedade. A distinção entre setor público e privado - que era atributo da esfera pública - é substituída pela interconexão progressiva entre as duas esferas, anulando as bases da esfera pública burguesa. $O$ Estado passa a atuar de forma proeminente na economia, com o intento de resguardar a integridade do capitalismo e de prevenir e minimizar conflitos sociais. Os meios de comunicação de massa impõem um pseudoconsenso, não por meio do engajamento deliberativo dos cidadãos, mas 
por meio da manipulação. Agora, a esfera pública se vincula a um Estado burocrático, que a usa para legitimar a ordem vigente.

Em obras posteriores a Strukturwandel der Öffentlichkeit, Habermas (1962, 1971, 1968) modifica sua estrutura teórica relativa à discussão sobre a esfera pública, especificamente no prefácio à edição de 1971 de Theorie und Práxis e, em Technik und Wissenschaft als Ideologie, lança uma inovação: a interligação entre técnica e ciência. Sua estratégia teórica visa tematizar em que medida a cientifização da política inspirou a questão do esvaziamento do engajamento democrático do cidadão.

Sob essa ótica, em Technik und Wissenschaft als Ideologie, Habermas (1968) explora a interconexão entre Estado e sociedade civil como um fato produzido pelos processos de racionalização e de burocratização do Estado intervencionista em sociedades capitalistas avançadas e pautadas pelo crescimento da tecnocracia. Já a "[...] nova configuração político-econômica decorreu da substituição do capitalismo liberal pelo capitalismo intervencionista, marcado pela burocratização e por uma interligação entre ciência e técnica." (BUNCHAFT, 2014, p. 160). Agora, a categoria da esfera pública é explicada por meio da diferenciação entre duas formas de ação.

Na década de 1970, Habermas (1973) delineia uma nova estrutura conceitual quanto à categoria esfera pública, pressupondo uma perspectiva dualista de sociedade. Com isso, as sociedades capitalistas avançadas subdividem-se em sistemas socioculturais, políticos e econômicos. Segundo Bunchaft e Rissi (2014, p. 160), a distinção entre ação comunicativa e ação instrumental seria a premissa da estrutura conceitual futura, que presumiria a perspectiva dualista entre sistema e mundo da vida.

Para Habermas (1973), a legitimação tecnocrática depreendida pela exclusão de questões práticas da esfera pública suscita a lealdade das massas, inspirando cidadãos despolitizados, que passam a atuar segundo um sistema de ação racional dirigida a fins. A inexistência de participação democrática impede a conscientização das contradições do sistema capitalista.

Em Legitimationsproblem im Spätkapitalismus, Habermas (1973) introduz, pela primeira vez, os conceitos de sistema e de mundo da vida. No capitalismo avançado, o Estado passa a assumir função proeminente na economia, superando o capitalismo liberal. Os mecanismos autodestrutivos do mercado são corrigidos pelo intervencionismo estatal, com o fito de controlar as crises econômicas. No entanto, de acordo com Habermas (1973), tal intervencionismo estatal nas sociedades capitalistas avançadas é insuscetível de superar as contradições do sistema no sentido de garantir crescimento econômico, evitando crises e protegendo socialmente o cidadão.

De acordo com Bunchaft e Rissi (2014), na segunda metade da década de 1980, no prefácio à terceira edição de Theorie des kommunikativen Handelns, Habermas (1985) modifica sua estrutura teórica e incorpora a ideia da relevância de um revigoramento do institucional, por intermédio de um refluxo do mundo da vida. A conexão entre sistema e mundo da vida não implicaria mais o fluxo de mão única, mas passaria a contemplar a ideia de um duplo fluxo, entre sistema e mundo da vida.

Para Lubenow (2007, p. 179), no prefácio de 1990, em Vorwortzur Neuauflage, a questão fundamental era “[...] pensar um modelo de esfera pública não apenas defensivo, mas também da inversão da direção dos fluxos de comunicação que se entrecruzam na esfera pública, de influência e efetivação do potencial político do modelo comunicativo de esfera pública nos arranjos político-ins- 
titucionais." Tal perspectiva, como ensina Lubenow (2012, p. 202), corresponde a esferas públicas autônomas que não integram o sistema político administrativo, mas "[...] que articulam e organizam a influência política por meios públicos de comunicação, participação e deliberação, contribuindo, assim, para a tematização, discussão pública e tomada de decisões."

Nessa fase, conforme preconiza Lubenow (2007), a estratégia conceitual habermasiana (1990), em Vorwortzur Neuauflage, é tratar também dos mecanismos institucionais constitutivos do funcionamento do ordenamento político. No entanto, como sublinha Lubenow (2007, p. 180), "[...] o conteúdo normativo de um conceito de democracia não pode se restringir a arranjos constitucionais do Estado Constitucional Democrático. Por isso, a referência à discussão da esfera pública vinculada à redescoberta da sociedade civil."

Não obstante, essa reviravolta conceitual ainda não contempla claramente o nexo entre as esferas públicas informal e formal, já que ambas se relacionam e, como fluxos comunicativos que emergem do mundo da vida, alcançam o poder político-administrativo (BUNCHAFT; RISSI, 2014). Nesse momento, Habermas (1990) concebe a esfera pública como direcionada para dois processos: um comunicativo, que legitima o poder político, e um com pretensões manipulativas.

Apesar de tais aportes teóricos, especificamente no que diz respeito à afirmação dos mecanismos institucionais e à ideia de sociedade civil, a esfera pública delineada em Vorwort zur Neuauflage não tem potencialidade de superar o modelo de sitiamento. De acordo com Lubenow, Habermas (1990) reafirma, de forma pessimista, a incapacidade da esfera pública de se contrapor à influência dos meios de comunicação de massa.

Por fim, em Faktizität und Geltung, o objetivo de Habermas (1992a) agora não mais se direciona à ideia de sitiamento por ele formulada em Theorie des kommunikativen Handelns (1981), mas para um processo de autodemocratização interno do sistema (BUNCHAFT; RISSI, 2014). Nesse livro, percebe-se uma nova estrutura teórica assentada em um modelo de eclusas que atribui à esfera pública papel mais ofensivo. Essa renovação teórica inspirou a compreensão original sobre a conexão entre poder comunicativo e poder administrativo instituído no sistema político (BUNCHAFT; RISSI, 2014).

Com efeito, a modificação conceitual fundamental sobre a concepção de esfera pública é delineada no prefácio de 1990 de Strukturwandel der Öffentlichkeit (1990), entretanto, seu papel mais ativo é ampliado em Faktizität und Geltung (1992a). No prefácio de 1990, em Strukturwandel der Öffentlichkeit, a temática principal indaga: a sociedade civil tem poder para mobilizar e para articular os impulsos comunicativos racionalizados na esfera pública e direcioná-los ao poder político-administrativo? Assim, em Faktizität und Geltung, Habermas (1992a) pretende se contrapor às perspectivas liberais, por meio de um modelo discursivo de esfera pública conectado à privada.

Em Faktizität und Geltung, Habermas (1992a) realça concepções que são essenciais à sua construção conceitual: esfera pública e sociedade civil. Nesse ponto de vista, a sociedade civil é a esfera pública institucionalizada. O núcleo institucional da sociedade civil é formado por associações, por organizações livres, não estatais e não econômicas, as quais ancoram as estruturas comunicativas da esfera pública nos componentes sociais do mundo da vida. A sociedade civil é constituída por 
movimentos, organizações e associações, os quais percebem os ecos sociais que ressoam nas esferas privadas, condensam-nos e os transmitem, a seguir, para a esfera pública política.

Nesse quadro teórico, Habermas (1992a) percebe, no núcleo da sociedade civil, a institucionalização de discursos que objetivam soluções para problemas que se transformam em questões de interesse geral no âmbito de esferas públicas, conduzindo-os para a esfera política. A esfera pública passa a ser concebida como um sistema de alarmes, dotado de sensores sensíveis que irão perceber, problematizar e tematizar determinados problemas, de modo a serem assumidos pelo Poder Legislativo, convertendo-os em leis.

Ao ensejo, os processos democráticos atuam como filtros que selecionam temas e contribuições, os quais são sintetizados pelos fluxos comunicativos, transformando-se em opiniões públicas sobre temas específicos. A possibilidade de influência política que os atores alcançam sobre a comunicação pública deve encontrar fundamento em um assentimento de um público de sujeitos privados, que devem ser convencidos por meio de argumentos e da justificação pública razoável.

Habermas (1992a), em Faktizität und Geltung, assinala que a esfera pública possui duplo aspecto, sendo constituída por atores sociais que participam da esfera pública e por aqueles que se utilizam da esfera pública formada a fim de dominá-la, como, por exemplo, os grandes grupos de interesse que agem estrategicamente. Por outro lado, ninguém pode ser legitimamente excluído desses processos discursivos e não devem existir coações externas, preservando-se a integridade dos pressupostos comunicativos. Não deve, igualmente, haver coações internas, porquanto todos os participantes são considerados livres e iguais, com o direito de introduzir, questionar e problematizar temas e contribuições.

Outrossim, a teórica Fraser (1997) estabeleceu uma série de críticas à concepção habermasiana de esfera pública. Em suas inferências, a autora aduz que o modelo liberal de esfera pública burguesa pressupunha a separação entre sociedade civil e Estado, e era apenas capaz de promover weak publics, "[...] cujas práticas deliberativas consistem exclusivamente na formação da opinião e não envolvem também a tomada de decisão."

Já a soberania parlamentar funciona como uma esfera pública dentro do Estado, constituindo o que Fraser $(1992,1997)$ denomina strong publics. Uma vez que a deliberação pública culmina em decisões legalmente vinculantes, o parlamento é o lócus da autorização discursiva para o uso do poder do Estado. Defende, ainda, a possível proliferação de strong publics na forma de instituições autoadministradas. Em locais de trabalho, em comunidades residenciais e em universidades surgem esferas públicas institucionais internas que poderiam ser arenas tanto para a formação de opinião quanto para a tomada de decisão.

A força da opinião pública é potencializada quando o corpo de representantes é empoderado para traduzir essa opinião em decisões imperativas. A questão fundamental é permitir que as estruturas democráticas estabeleçam mecanismos de coordenação entre as diferentes esferas públicas institucionais de maneira a contemplar os diversos públicos. Conclui que o modelo de esfera pública burguesa não atende aos propósitos da teoria crítica, posto que é insuscetível de teorizar sobre strong publics e weak publics e de elucidar as relações entre ambos. 
Fraser (1992) pondera que a ideia de contrapublicidade pode viabilizar aos movimentos sociais a possibilidade de ampliar a gama de conhecimento de injustiças publicamente articuladas por meio de formas críticas de comunicação expressas, em termos de "contrapúblicos", que são "[...] arenas discursivas paralelas nas quais os membros dos grupos socialmente subordinados inventam e circulam contradiscursos para formular interpretações opostas de suas identidades, interesses e necessidades." (FRASER, 1992, p. 123). Cumpre dizer que tais críticas tiveram reflexos na concepção habermasiana (1992b) de esfera pública, que terminou por rever sua percepção inicial.

Habermas (1992b), no ensaio Further Reflections on the Public Sphere, passou a defender a coexistência de esferas públicas concorrentes com ênfase nas dinâmicas dos processos de comunicação que são excluídos da esfera pública dominante. Destaca que a existência da multiplicidade de esferas públicas inspira o acesso mais amplo à esfera pública. A esfera pública, então, configuraria uma rede discursiva estabelecida pela multiplicidade de públicos transversais sobrepostos e em dimensões diversas, mas conectada por algum aspecto quanto ao conteúdo, às relações sociais, entre outros (HABERMAS, 1992b, p. 425).

Para Fraser (2009), em Faktizität und Geltung, Habermas (1992a) dispensava atenção especial à temática da eficácia e do déficit de legitimidade da opinião pública nos Estados democráticos. O direito seria o mecanismo que revelaria a potencialidade de traduzir o poder comunicativo para o poder administrativo. Nas palavras de Fraser, Habermas distingue uma circulação de poder pública, democrática, na qual públicos fracos influenciam públicos fortes, que, por sua vez, "[...] controlam o aparato estatal administrativo da circulação de poder não pública e não democrática, na qual poderes sociais privados e interesses burocráticos entrincheirados controlam a produção legislativa e manipulam a opinião pública." (HABERMAS, 1992a apud FRASER, 2009, p. 84).

Em Faktizität und Geltung, Habermas (1992 apud FRASER, 2009, p. 85) cria uma "[...] concepção mais completa sobre os déficits de eficácia da opinião pública nos Estados democráticos." Não obstante, apesar da renovação conceitual estabelecida em Faktizität und Geltung, o autor não atinge o objetivo de superar a estrutura westfaliana, associando a ideia de opinião pública ao âmbito da jurisdição soberana estatal. Fraser (2009) pondera que Habermas (1998), embora tematize uma forma pós-nacional de integração social - que propugna a desvinculação do Estado democrático da cidadania etnocultural - acaba endossando a concepção de publicidade exclusivamente territorial.

Até 2011, percebia-se ambiguidade em seus ensaios sobre a Europa. Para Boon (2007), Habermas oscilava entre a defesa de um modelo prescritivo fino de patriotismo constitucional e a proposta de uma noção forte de autocompreensão europeia. Essa tensão entre a abordagem fina e a densa se manifesta na própria interpretação de Habermas (1998), segundo a qual cada comunidade política interpreta princípios constitucionais à luz de sua própria história. Habermas (1998) tem gradativamente delineado uma estrutura teórica que ultrapassa o modelo fino de integração política, passando a defender a concepção particular de autocompreensão europeia.

Em Inclusion of the Other (HABERMAS, 1998), alega que não poderá existir um Estado federativo europeu se não forem determinados, no horizonte de uma cultura política, uma opinião pública em âmbito europeu, uma sociedade civil com associações representativas de interesses, de 
organizações não estatais e de movimentos de cidadania, um sistema político partidário concebido em face de arenas europeias, em suma, um contexto comunicativo que transcenda as fronteiras de opiniões públicas de inserção meramente nacional.

Somente em Sobre a Constituição da Europa - um ensaio, Habermas (2012) finalmente soluciona essa ambiguidade em sua obra. Até esse momento, apenas denunciava a incapacidade dos Estados nacionais em administrar o mercado global, denunciando o déficit democrático da integração europeia e suas instituições, ainda partindo do Estado-Nação como a esfera para a prática democrática. Na obra, Habermas (2012) assevera, de maneira mais cristalina, que as instituições transnacionais apenas alcançam legitimidade quando garantem a formação democraticamente estruturada de opinião e de vontade dos cidadãos europeus, que atuam como cidadãos de seus países e como cidadãos europeus, em uma democracia mundial.

Com a sociedade mundial complexa - a qual restringe a esfera de atuação dos Estados nacionais - estes não têm mais capacidade de solucionar determinados problemas complexos, recorrendo a organizações internacionais. Segundo Habermas (2012), a única forma que os Estados nacionais têm de se oporem às coerções sistêmicas da sociedade mundial seria a ampliação da esfera pública, por meio da transnacionalização da soberania popular.

Portanto, não basta que as competências transferidas do Estado nacional para as instâncias supranacionais sejam somente juridificadas na forma de tratados internacionais, mas, sim, por um procedimento democraticamente estruturado, em que cidadãos de um Estado afetado deveriam ter a prerrogativa de deliberarem com cidadãos dos outros Estados, em um procedimento discursivo de criação de uma legislação supranacional. Dessa maneira, Habermas (2012, p. 81) lança a forma transnacionalmente ampliada de solidariedade civil: o Tratado de Lisboa "[...] deveria fortalecer a capacidade de ação da União Europeia com a incorporação do Conselho Europeu na estrutura institucional."

Habermas (2012) sustenta a criação de uma Constituição europeia, cuja futura criação viabilizaria emergir a cooperação constituinte entre cidadãos e Estados na qual a comunidade internacional existente entre Estados seria complementada por uma comunidade cosmopolita. ${ }^{4}$

O Parlamento mundial, como intérprete da Carta das Nações Unidas, deveria estar atento a essa dupla perspectiva. A comunidade mundial não teria mais um caráter estatal, e os Estados deveriam se subordinar às resoluções do Conselho de Segurança. Ademais, o Parlamento mundial, no entendimento de Habermas (2012, p. 101), deveria “[...] orientar os debates sobre as condições do fundo da justiça global, e o Conselho de Segurança tomaria as decisões importantes, sendo estas, porém, amplamente judicializadas e controladas pelas Cortes."

\footnotetext{
4 É clara a assertiva de Habermas (2012, p. 95): "Os Estados nacionais formariam, ao lado dos cidadãos do mundo, o segundo sujeito constituinte da comunidade mundial. Pois os cidadãos cosmopolitas têm ou teriam ainda boas razões para se ater ao papel constitutivo de seus estados em todo o âmbito supranacional. Na medida em que os cidadãos já realizaram nessas formas históricas uma parte da justiça política escoada institucionalmente, eles podem nutrir o desejo fundamentado de que seus estados nacionais se mantenham como entidades coletivas nos respectivos níveis superiores de organização. A composição de uma Assembleia geral de representantes dos cidadãos e dos Estados asseguraria que as perspectivas concorrentes sobre a Justiça fossem levadas em consideração pelos cidadãos do mundo, por um lado, e pelos cidadãos do Estado, por outro, alcançando assim um equilíbrio."
} 
Sob essa ótica, um contexto comunicativo global inspirado na transnacionalização da soberania popular a partir da tecnologia digital permitiria a todas as populações a formação de um juízo moralmente justificado sobre o conteúdo das decisões tomadas no âmbito das Nações Unidas.

Aprofundando a temática da transnacionalização da soberania popular, Fraser (2014) avalia que, em face da emergência de redes financeiras e do capital financeiro global, o Estado nacional perde o controle sobre a política nacional. Aqueles que protestaram contra o domínio do Fundo Monetário Internacional (FMI) e do Banco Mundial têm insistido que as regras que governam negócios, produção e finança são estabelecidas transnacionalmente pelas agências responsáveis pelo capital global, transcendendo as fronteiras nacionais. E questiona: se surgem agências que estabelecem mecanismos de governança econômica para além das fronteiras do espaço westfaliano, restringindo e limitando a política nacional, como pode a opinião pública dos cidadãos assumir força efetiva?

Se o sistema capitalista é responsável pela pobreza global, como pode o que passa pela opinião pública transnacional ser considerado legítimo, quando aqueles efetivamente afetados pelas políticas não podem possivelmente se engajar discursivamente e problematizar sua legitimidade como parceiros plenos? Poderia a opinião pública crítica ser gerada em larga escala e mobilizada como força política legítima e efetiva?

De acordo com Fraser (2014), as esferas públicas assumem dimensão mais transnacional com respeito a cada elemento constitutivo da opinião pública. O quem da comunicação configura uma multiplicidade de interlocutores dispersos que não constituem um demos. $\bigcirc$ o que da comunicação transcende o interesse nacional westfaliano enraizado na economia nacional e surge a partir de vastas áreas do mundo, inspirando solidariedades cada vez mais amplas. $O$ onde se torna o ciberespaço desterritorializado. $\bigcirc$ como da comunicação agora reflete a rede translinguística ampla de culturas sobrepostas. $\bigcirc$ quem mistura poderes públicos e privados transnacionais, que não são nem facilmente identificáveis, nem facilmente responsabilizados.

A questão, portanto, contempla: como as esferas públicas poderiam exercer um papel crítico democrático por meio da opinião pública legítima, no sentido forte? Para alcançar tal objetivo, Fraser (2014) elenca dois pressupostos: o primeiro é a condição de inclusividade, que é satisfeita quando o debate democrático se mostra aberto a todos os afetados pelos efeitos da discussão; no segundo, enfatiza a condição de paridade, que surge quando todos os participantes desfrutarem de igualdade de chances para expressar interesses e para mover questões na agenda.

Enquanto a condição da inclusividade se relaciona às questões do quem está autorizado a participar em discussões públicas, a condição de paridade diz respeito à questão do como, no sentido de que em que termos os interlocutores se engajam uns com outros. A condição da paridade e da inclusividade não se conecta mais à cidadania compartilhada em uma comunidade definida, pois a primeira não estabelece mais os laços legítimos de inclusividade, nem a paridade de participação nas deliberações públicas se atém às fronteiras do estado territorial.

Estabelecidas tais considerações, surge a indagação: se a cidadania perdeu a capacidade de demarcar tanto o quem quanto o como da opinião pública legítima, como a exigência de inclusividade deveria ser compreendida? 
Segundo Fraser (2014), para que a teoria da esfera pública possa manter sua orientação crítica, em um mundo pós-westfaliano, a condição de inclusividade deve sofrer uma releitura, renunciando à identificação automática da exigência de inclusão com a cidadania compartilhada de um estado específico. Em Habermas (apud FRASER, 2014), aqueles que podem ser sujeitos relevantes para a comunicação cotidiana (mas que não são cidadãos formais do território) são excluídos do debate. No entanto, fica o questionamento: como interpretar o "princípio de todos os afetados" em uma esfera pública crítica pós-westfaliana sem passar pelo filtro da cidadania?

Em Reframing Justice in a Globalizing World, que posteriormente passou a integrar a obra Scales of Justice, Fraser $(2005,2009)$ doutrina que o "princípio de todos os afetados" pressupõe que:

[...] o que constitui um grupo de pessoas em membros de sujeitos de justiça de uma mesma categoria não é a proximidade geográfica, mas sua coimbricação em um enquadramento institucional ou estrutural comum que estabelece as regras fundantes que governam suas interações sociais, moldando, assim, suas respectivas possibilidades de vida segundo padrões de vantagem ou desvantagem. (FRASER, 2009, p. 24).

Segundo Fraser (2009), o "princípio de todos os afetados" deve ser interpretado dialogicamente por meio da troca de argumentos em uma deliberação democrática. A grande questão é: quem será incluído nesse processo de deliberação democrática que decidirá na interpretação politicamente legítima do princípio de todos os afetados?

Sob esse prisma, o grande problema do "princípio de todos os afetados", para Fraser (2008, 2009), era o "efeito-borboleta", que pressupunha o fato de todos serem afetados por tudo. Pretendendo evitar a reductio ad absurdum, Fraser (2008) defendeu a necessidade de resgatar um padrão normativo qualitativo que fosse capaz de identificar níveis de efetividade suficientes para conferir uma base moral.

Assumindo esse desafio, Fraser (2008, 2009), no ensaio Abnormal Justice (que posteriormente comporá a obra Scales of Justice), abandonou o "princípio de todos os afetados", substituindo-o pelo "princípio de todos os sujeitados", que pode ser sintetizado nos seguintes termos:

Nesta visão, o que transforma uma coletividade de pessoas em sujeitos pares da justiça não é a cidadania ou nacionalidade compartilhada, nem a posse comum de personalidade abstrata, nem o simples fato de interdependência causal, mas sim a sujeição conjunta a uma estrutura de governança que determina as regras fundantes que governam suas interações. (FRASER, 2010, p. 65).

Em suma, o papel do "princípio de todos os afetados" é "[...] especificar quem deveria ser envolvido em públicos preocupados em construir estruturas de governança enquanto que o princípio de todos os sujeitados identifica quem deveria ser incluído em públicos que são responsáveis por estruturas de governança construídas." (OWEN, 2014, p. 123-124). Fraser (2009) sustentava que o "princípio de todos os afetados" era aberto a uma pluralidade de interpretações razoáveis, de forma que a delimitação do seu alcance pressupunha as contribuições em um amplo debate público sobre seu significado. 
Em síntese, a vantagem do princípio de todos os sujeitados é que oportuniza a cada um ser membro de um público e, ao mesmo tempo, ser sujeito de justiça. Já a vantagem do princípio de todos os afetados, conforme Owen (2014, p. 124), é que permite "[...] acomodar a intuição de que, sermos afetados de formas moralmente relevantes pelas ações ou decisões dos outros, tem importância independentemente de nós sermos sujeitos de uma estrutura de governança."

Quando tais estruturas transcendem as fronteiras de um território específico e da cidadania compartilhada, as respectivas esferas públicas devem ser transnacionais, sob pena de a opinião que elas geram não alcançar legitimidade. Fraser (2014) sublinha que a inclusividade e a paridade estão conectadas, e que a opinião pública é legítima se - apenas - resultar de um processo do qual todos os potencialmente afetados podem participar como parceiros plenos em sua construção independentemente da cidadania compartilhada.

Trata-se de uma interpretação pós-westfaliana de legitimidade da opinião pública que incorpora um potencial e um padrão crítico para avaliar formas de publicidade existentes na era atual. Fraser (2014) defende, ainda, a atuação de movimentos antissistêmicos e de militância independente - como o Occupy e o Fórum Social Mundial - como estratégia de construção de centros contra-hegemônicos de opinião e de formação da vontade, distanciados das esferas do poder institucionalizado, viabilizando a ação direta de contrapúblicos subalternos.

Dialogando com Fraser (2014), Kurusawa (2014) sustenta um tipo de cosmopolitismo anarquista estabelecido pela atuação autônoma de movimentos radicais e de grupos da sociedade civil global, cuja estratégia é o impacto político da contrapublicidade, que surge por meio do ativismo político transnacional. Também analisa como essa noção pode informar o cosmopolitismo anarquista tanto para interpretar práticas da luta política pela justiça global quanto para complementar a teoria de esfera pública transnacional, delineada por Fraser.

Kurusawa (2014, p. 81) ensina que a realização da justiça global e a transformação estrutural da ordem mundial na direção de um universalismo igualitário não podem ser alcançadas por uma opinião pública construída nas instituições formais da governança global, mas pela "[...] concretização da contrapublicidade em formas de auto-organização e autogoverno democráticas dentro da sociedade civil global e nacional."

Ademais, a ideia de contrapúblicos subalternos pode promover o autogoverno e as práticas de muitos grupos radicais e movimentos ativistas da sociedade civil global. Assim, rejeita esquemas que democratizariam a governança global pela transferência de poderes de instituições nacionais para parlamentos transnacionais responsáveis perante públicos e eleitorado transnacionais, pois tal estratégia não revelaria capacidade de fortalecer o poder da opinião pública.

Portanto, quando os mecanismos decisórios das autoridades públicas se situam dentro das instituições formais de governança global, acabam sendo plenamente ou parcialmente desarticulados da esfera pública transnacional (KURUSAWA, 2014, p. 86). Consequentemente, há perda de autonomia da esfera pública transnacional como instância crítica das instituições oficiais de governança global. 
Nesse ponto, as demandas mais radicais de grupos da sociedade civil nacional e global são neutralizadas pelas instituições financeiras globais. Por sua vez, os poderes públicos tornam-se mecanismos por meio dos quais os mecanismos legais e administrativos passem a colonizar o mundo da vida, regulando a atuação de movimentos da sociedade civil global (KURUSAWA, 2014, p. 89).

Ainda para Kurusawa (2014), a natureza das instituições formais, se transnacionais ou nacionais, não evita a funcionalização do imput da sociedade civil, incorporando esta última em um processo autopoiético que expande o poder das instituições formais. Apenas um projeto de distanciamento engajado das esferas institucionais formais de governança global evitaria a lógica da cooptação. Apenas a concretização da lógica da contrapublicidade em coletivos auto-organizados pode dissipar a heteronomia, restaurando a capacidade de autodeterminação.

Kurusawa (2014, p. 90) preconiza a esfera pública transnacional como “[...] um conjunto de redes de conselhos autoadministrados e de espaços igualitários ancorados em corpos coordenados em diversas esferas geográficas praticando formas de democracia direta ou quase diretas." Essas redes podem concretizar um cosmopolitismo anarquista, que se contrapõe a reformas formais institucionais, impedindo a cooptação.

Explica ser necessário expandir a eficácia política da compreensão de opinião pública, por meio de formas não institucionais e não institucionais de contrapúblicos subalternos, independentemente da implementação das decisões dos poderes públicos. Ressalta, ainda, não ser claro, na teoria de Fraser (2014), se há realmente lugar para a centralidade de instituições autogovernadas como strong publics na esfera pública transnacional e de que forma a teórica as compreende no contexto pós-westfaliano.

\section{Conclusão}

Diante do exposto, consoante sublinha Cassese (2010, p. 83), o tradicional binômio Estado-cidadão tem sido questionado nas sociedades contemporâneas. Tal compreensão supera as doutrinas tradicionais defendidas por autores como Giannini (1950) e Zanobini (1955). O surgimento das minorias na Europa oriental e dos apátridas na Europa meridional e o fenômeno da desnacionalização tornaram evidente a incapacidade institucional das Nações-Estado europeias de concretizar plenamente os direitos humanos de determinados grupos de indivíduos.

Sob essa ótica, assume relevância a Declaração dos Direitos do Homem de 1789, porquanto implicou uma ruptura com autocompreensões de natureza divina e práticas costumeiras. De um lado, enfatizamos a perspectiva de Arendt (1989), segundo a qual a definição de direitos humanos como direitos que decorrem da própria ideia de homem se contrapõe à condição humana baseada na pluralidade, que também é fundamental à dignidade humana.

De outro lado, consoante Delmas-Marty (2010), assumem relevância os "bens públicos mundiais" pelo seu potencial em reduzir as tensões entre hominização unificadora e humanização relativista, inspirando o florescimento de valores universalizáveis. Portanto, sustenta-se que os direitos humanos demandam a sua efetividade não mais vinculada às fronteiras do Estado, mas em face 
da condição humana. Indubitavelmente, o espaço virtual é uma arena privilegiada para exercício dos direitos humanos nas sociedades contemporâneas.

De fato, o isolamento dos domicílios não pode se constituir em um óbice para a troca de ideias e o desenvolvimento da criatividade. A interação em rede deve servir para o compartilhamento dessa informação e o fomento da participação política de forma consistente. Nota-se uma tendência de que no espaço virtual se reproduzam as desigualdades existentes na vida real. Dessa forma, a disparidade econômica pode ser reproduzida na falta de acesso à internet, no que se denomina exclusão digital. Assim, a questão da inclusão digital não se limita ao acesso à internet.

O requisito, por si só, não supre a educação precária e deficiente, visto que o acesso precisa vir acompanhado da educação escolar básica, a fim de que a quantidade de informação seja selecionada e compreendida de maneira qualificada, visando à formação de uma cidadania comprometida com os valores que expressam a defesa dos direitos humanos, desde a perspectiva de Pérez Luño (2004). A sociedade democrática reivindica o pluralismo informativo, o livre acesso e a livre circulação de informação. Desse modo, o desafio consiste em pensar a internet como novo espaço virtual, fazendo com que sirva para qualificar a democracia, mantendo-se a liberdade, mas regulando alguns aspectos, para que não se tenha um far west informático.

Segundo Frosini (1984), a informática representa um novo instrumento de poder político e social. Assinala que as sociedades contemporâneas são marcadas pela produção, pela circulação e pelo consumo de informação - fato sem precedentes na história da humanidade (FROSINI, 1984, p. 30).

Sob esse prisma, a Carta de Nice - que após foi ratificada no Monastério dos Jerônimos, em Lisboa - elenca direitos que são aglutinados em torno de quatro valores básicos, a saber, dignidade, liberdade, igualdade e solidariedade. $O$ documento, que contempla os direitos fundamentais da União Europeia, demonstra estar em sintonia com as questões oriundas do ciberespaço, já que a proteção dos dados pessoais configura direito autônomo, o que vem a positivar as preocupações de Frosini (1984).

Com efeito, a virtualidade modifica os conceitos de cidade física, mas continua necessitando do caráter de educação cívica, para que o contato em rede sirva à civilização. $O$ desafio consiste, assim, em que o espaço virtual não seja a mera reprodução das mazelas existentes na vida real, mas possibilite a qualificação do debate - e não apenas a manipulação da opinião pública. Nesse ponto, as contribuições de Habermas e de Fraser são fundamentais.

A estratégia habermasiana (1992a, 2012), estabelecida em Faktizität und Geltung, no que se refere ao modelo de eclusas que concede à esfera pública papel mais ofensivo, e os aportes teóricos delineados em Sobre a Constituição da Europa, em relação à transnacionalização da soberania popular, revelam potencialidade para atender aos desafios propostos pela necessidade de conceber o espaço de informação na internet como uma arena de efetividade dos direitos humanos.

Sob esse prisma, consoante Habermas (2012), um contexto comunicativo global que surge a partir do fenômeno da transnacionalização da soberania popular a partir da tecnologia digital permitiria aos cidadãos do mundo a formação de um juízo moralmente justificado e a possibilidade de 
tematizar discursivamente as decisões assumidas no âmbito das Nações Unidas, atribuindo maior efetividade aos direitos humanos.

Não obstante, sustenta-se que a estrutura conceitual de Fraser (2008), especialmente a centralidade do "Princípio de todos os sujeitados", evidencia maior alcance para atender democraticamente à construção de uma opinião pública transnacional capaz de encarar os desafios da inclusividade e da paridade, contemplando maior potencial crítico para combater as formas de publicidade manipulativas.

Defende-se que a interação em rede pode incrementar a deliberação democrática em um mundo pós-westfaliano. Como salienta Kurusawa (2014), a ideia de contrapúblicos subalternos sustentada por Fraser $(1992,1997)$ pode representar um referencial relevante para informar a estratégia de oposição movida pelo distanciamento engajado das políticas institucionais formais que se formam por movimentos relevantes do ativismo da sociedade civil global. Trata-se de redes transnacionais contra-hegemônicas que, em sua opinião, informarão um cosmopolitismo anarquista efetivado por movimentos radicais da sociedade civil global. Tal perspectiva pode atribuir maior potencial crítico à revisão pós-westfaliana da teoria da esfera pública.

Com efeito, em relação ao enfrentamento do principal problema objeto deste trabalho, conclui-se que o espaço de interação na internet pode potencializar a democracia no caminho da concretização dos direitos humanos, por meio da lógica da contrapublicidade.

Assim, propugna-se a aplicação do conceito de contrapúblicos à revisão pós-westfaliana do conceito de esfera pública e seu potencial para capturar as estratégias formais e não governamentais da atuação de movimentos ativistas da sociedade civil global, como o Fórum Social Mundial e as lutas transnacionais em rede voltadas à defesa dos direitos humanos. Logo, somente essas esferas públicas contra-hegemônicas podem inspirar potencial crítico para denunciar injustiças globais, fugindo da lógica da cooptação e transformando arranjos sociais de baixo para cima.

Finalmente, é importante que o mundo virtual tenha sua normatização, sob pena de se transformar em um verdadeiro far west informático. Outrossim, o ciberespaço se constitui - ou pode se constituir - um espaço para o exercício dos direitos humanos e para a participação, inspirando o controle social, a partir da informação disponibilizada em rede, de seu acesso e de seu compartilhamento.

\section{Referências}

ARENDT, Hannah. As origens do Totalitarismo. São Paulo: Companhia das Letras, 1989.

ARISTÓTELES. A Política. São Paulo: Ediouro, 1998.

BOON, Vivienne. Habermas's Writings on Europe: not habermasian enough. Ethical Perspectives, European Centre for Ethics, v. 14, n. 3, p. 287-310, 2007.

BUNCHAFT, Maria Eugenia. Esfera pública, reconhecimento e minorias: o diálogo Habermas-Fraser. Scientia Juris, Londrina, v. 18, n. 1, 2014. 
BUNCHAFT, Maria Eugenia; RISSI, Rosmar. Lutas por reconhecimento, esfera pública e direitos fundamentais: uma reflexão sobre a perspectiva de Jürgen Habermas. Espaço Jurídico, Chapecó, v. 15, n. 2, 2014.

CASSESE, Sabino. A crise do Estado. Campinas: Saberes, 2010.

CASTELLS, Manuel. Redes de indignação e esperança: movimentos sociais na era da internet. Rio de Janeiro: Zahar, 2013.

CHEVALLIER, Jacques. O Estado pós-moderno. Tradução Marçal Justen Filho. Belo Horizonte: Fórum, 2009.

COUlANGES, Fustel de. A Cidade Antiga. 2. ed. São Paulo: Martin Claret, 2001.

DELMAS-MARTY, Mireille. Les forces imaginantes du droit. (III) - La refondation des pouvoirs. Paris: Seuil, 2007.

DELMAS-MARTY, Mireille. Vers une communauté de valeurs. Paris: Seuil, 2010.

FRASER, Nancy. Abnormal Justice. Critical Inquiry, Chicago, v. 34, i. 3, p. 393-422, 2008.

FRASER, Nancy. Justice Interruptus - Critical Reflections on the PostSocialist Condition. New York: Routledge, 1997.

FRASER, Nancy. Reframing Justice in a Globalizing World. New Left Review, London, i. 36, p. 1-19, Nov./Dec. 2005.

FRASER, Nancy. Rethinking the Public Sphere: a Contribution to the Critique of Actually Existing. Democracy. In: CALHOUN, Craig (Org.). Habermas and the Public Sphere. Cambridge: Mit Press, 1992.

FRASER, Nancy. Scales of Justice - Reimagining Political Space in a Globalizing World. New York: Columbia University Press, 2009.

FRASER, Nancy. Scales of Justice - Reimagining Political Space in a Globalizing World. New York: Columbia University Press, 2010.

FRASER, Nancy. Transnationalizing the Public Sphere: on the Legitimacy and Efficacy of Public Opinion in a Post-Westphalian World. In: FRASER, Nancy (Org.). Transnationalizing the Public Sphere. Massachusetts: Polity Press, 2014.

FROSINI, Vittorio. Cibernetica, Derecho y Sociedad. Madrid: Tecnos, 1982.

FROSINI, Vittorio. Diritto alla riservatezza e calcolatori elettronici. In: ALPA, Guido; BESSONE, Mario (Org.). Banche dati, telematica e diritti della persona. Quaderni di Diritto Comparato. Padova: Cedam, 1984.

FROSINI, Vittorio. La protezione della riservatezza nella società informatica. Informatica e Diritto, v. 1, jan./abr. 1981. 
FROSINI, Vittorio. L'uomo artificiale: etiica e diritto nell'era planetaria. Milano: Spirali Edizione, 1986.

GIANNINI, Massimo Severo. Lezione di diritto amministrativo. Milano: Giuffrè, 1950.

HABERMAS, Jürgen. A Berlin Republic: Writings on Germany. Lincoln: University of Nebraska Press, 1997.

HABERMAS, Jürgen. Direito e democracia: entre facticidade e validade. 2. ed. Rio de Janeiro: Tempo Brasileiro, 2003. v. 2.

HABERMAS, Jürgen. Faktizität und Geltung: Beiträge zur Diskurstheorie des Rechts und des Demokratischen Rechtsstaats. Frankfurt: Suhrkamp, 1992a.

HABERMAS, Jürgen. Further Reflections on the Public Sphere. In: CALHOUN, Craig. Habermas and the Public Sphere. Cambridge, Massachusetts and London: The Mit Press, 1992b.

HABERMAS, Jürgen. Inclusion of the Other: Studies in Political Theory. Cambridge: Polity, 1998.

HABERMAS, Jürgen. Legitimationsproblem im Spätkapitalismus. Frankfurt: Suhrkamp, 1986.

HABERMAS, Jürgen. ¿̇Por qué Europa necesita una Constitución? New Left Review, Madrid, n. 11, nov./dic. 2001. Disponível em: <http://newleftreview.es/authors/jurgen-habermas>. Acesso em: 01 jan. 2014

HABERMAS, Jürgen. Sobre a Constituição da Europa - um ensaio. São Paulo: Ed. UNESP, 2012.

HABERMAS, Jürgen. Strukturwandel der Öffentlichkeit. Berlin, Neuwied: Luchterhand, 1962.

HABERMAS, Jürgen. Strukturwandel der Öffentlichkeit. Frankfurt: Suhrkamp, 1990.

HABERMAS, Jürgen. Technik und Wissenschaft als Ideologie. Frankfurt: Suhrkamp, 1968.

HABERMAS, Jürgen. Theorie des kommunikativen Handelns. Frankfurt: Suhrkamp, 1973.

HABERMAS, Jürgen. Theorie des kommunikativen Handelns. Frankfurt: Suhrkamp, 1981.

HABERMAS, Jürgen. Theorie des kommunikativen Handelns. Frankfurt: Suhrkamp, 1985.

HABERMAS, Jürgen. Theorie und Práxis: Sozialphilosophische Studien. Berlin, Neuwied: Luchterhand, 1963.

HABERMAS, Jürgen. Theorie und Práxis: Sozialphilosophische Studien. Frankfurt: Suhrkamp, 1971.

HESSEL, Stéphane. IIndignaos! Un alegato contra la indiferencia y a favor de la insurrección pacífica. Barcelona: Ediciones Destino, 2011.

JELLINEK, Georg. Teoría General del Estado. Reimpresión de la 2a edición alemana - 1905, editada por Editorial Albatros en el año 1954. Buenos Aires: Julio Cesar Faira Ed., 2005. 
KURUSAWA, Fuyuki. An Alternative Transnational Public Sphere? On Anarchist Cosmopolitanism in Post-Westphalian Times. In: FRASER, Nancy (Org.). Transnationalizing the Public Sphere. Massachusetts: Polity Press, 2014.

LIMBERGER, Têmis. O direito à intimidade na era da informática: o desafio da proteção dos dados pessoais. Porto Alegre: Livraria do Advogado, 2007.

LUBENOW, Jorge Adriano. A categoria de esfera pública em Jürgen Habermas. 2007. Tese (Doutorado em Filosofia)-Universidade Estadual de Campinas, Campinas, 2007.

LUBENOW, Jorge Adriano. A despolitização da esfera pública em Jürgen Habermas sob a perspectiva sociopolítica. Problemata, João Pessoa, v. 3, n. 1, p. 54-95, 2012.

MACKINNON, Emma Stone. Beyond recognition: Habermas's 'Constitutional Patriotism' as a response to Exclusion from the Public Sphere. Political Theory Workshop, Chicago: University of Chicago, Nov. 2013. Disponível em: <http://ptw.uchicago.edu/Mackinnon13.pdf>. Acesso em: 01 jan. 2014.

NORA, Simon; MINC, Alain. Informe Nora-Minc - La informatización de la sociedad. Madrid: [s.n.], 1982.

OWEN, David. Dilemmas of Inclusion. In: FRASER, Nancy (Org.). Transnationalizing the Public Sphere. Massachusetts: Polity Press, 2014.

PÉREZ LUÑO, Antonio Enrique. ¿Ciberciudania@ociudadanía.com? Barcelona: Gedisa, 2004.

PÉREZ LUÑO, Antonio Enrique. Derechos humanos, Estado de Derecho y Constitución. 10. ed. Madrid: Tecnos, 2010.

PÉREZ LUÑO, Antonio Enrique. La Filosofía del Derecho en perspectiva histórica. Estudios conmemorativos del 65 aniversario del autor. Homenaje de la Facultad de Derecho y del Departamento de Filosofía del Derecho de la Universidad de Sevilla. Sevilla: Servicio de Publicaciones de la Universidad de Sevilla, 2009.

PÉREZ LUÑO, Antonio Enrique. La Tercera Generación de Derechos Humanos. Navarra: ThomsonAranzadi, 2006.

PÉREZ LUÑO, Antonio Enrique. Manual de informática y derecho. Barcelona: Editorial Ariel, 1996.

PÉREZ LUÑO, Antonio Enrique (Org.). El derecho a la autodeterminación informativa. Problemas actuales de la documentación y la informática jurídica. Madrid: Tecnos, 1987.

PÉREZ LUÑO, Antonio Enrique. Derechos humanos, Estado de Derecho y Constitución. 10. ed. Madrid: Tecnos, 2010.

PÉREZ LUÑO, Antonio Enrique. Perspectivas e tendências atuais do Estado Constitucional. Porto Alegre: Livraria do Advogado, 2012.

SORG, Letícia; MACHADO, Juliano. O grito árabe pela democracia. Época, jan. 2011. Disponível em: <http://revistaepoca.globo.com/Revista/Epoca/0,EMI206605-15227,00-O+GRITO+ARABE+PELA+DEMOCRACIA.html>. Acesso em: 10 ago. 2014. 
STEIN, Ernildo. Sobre a Essência do Fundamento. Conferências e escritos filosóficos de Martin Heidegger. Tradução Ernildo Stein. São Paulo: Abril Cultural, 1979.

SUNSTEIN, Cass. Republica.com. Internet, democracia y libertad. Barcelona: Ediciones Paidós Ibérica, 2003.

UNIÃO EUROPEIA. Carta dos Direitos Fundamentais da União Europeia. 2000. Disponível em: <http://www.europarl.europa.eu/charter/default_pt.htm>. Acesso em: 27 set. 2014.

ZANOBINI, Guido. Scritti Vari di Diritto Pubblico. Milano: Giuffrè, 1955. 